Creative commons User License: CC BY-NC-ND

Abstracted by: EBSCOhost, Electronic Journals Service (EJS),

Google Scholar, Directory of Open Access Journals (DOAJ),

Journal Seek, Scientific Commons,

Food and Agricultural Organization (FAO), CABI and Scopus
Journal of Agricultural Extension

Vol. XX (X) XXXXXX, 20XX

ISSN(e): 24086851; ISSN(Print); 1119944X

http://journal.aesonnigeria.org

http://www.ajol.info/index.php/jae

Email: editorinchief@aesonnigeria.org

\title{
Rural Women's Participation in the Growth Enhancement Support Scheme in Abia State Nigeria
}

http://dx.doi.org/10.4314/jae.v20i2.2

\section{Umeh O. J.}

Department of Rural Sociology and Extension

Michael Okpara University of Agriculture Umudike, Abia State Nigeria.

Umehogechi2@yahoo.com (08037420857)

\section{Mba G. 0.}

Department of Rural Sociology and Extension

Michael Okpara University of Agriculture Umudike, Abia State Nigeria.

mbago@gmail.com (0805704666)

\section{Aghale D. N.}

Department of Plant Science and Biotechnology.

Michael Okpara University of Agriculture Umudike, Abia State Nigeria.

aghalenduka@yahoo.com (08134005735)

\section{Nwachukwu I.}

Department of Rural Sociology and Extension

Michael Okpara University of Agriculture Umudike, Abia State Nigeria.

nwachukwuike@ymail.com (08035485064)

\section{Abstract}

This work assessed the participation of rural women in the Growth Enhancement Support Scheme (GESS) in Abia State. Multistage random sampling procedure was used to select 120 farmers. Results indicated that 35.3\% of the registered women participated in the programme while $62.93 \%$ rated GESS as moderately effective. However, lack of electricity to power their phone (59.48\%), delay in receiving SMS (57.75\%) and inadequate quantity of inputs received (62.06\%) were constraints to active participation of women in the Scheme. Probit estimate of the relationship between the age, marital status, awareness, level of education, family size, extension contact, membership of social organizations and monthly income of the women and their level of participation in the Scheme showed that coefficient of awareness (0.205) was positive and significant while age $\left(-1.105^{\star}\right)$ and monthly income $\left(-1.915^{\star}\right)$ were negative and also significant. It is therefore recommended that the government improve on the technicalities of SMS delivery and quantity of inputs received through the scheme.

Keyword: Women, Participation, Growth Enhancement Support Scheme. 
Creative commons User License: CC BY-NC-ND

Abstracted by: EBSCOhost, Electronic Journals Service (EJS),

Google Scholar, Directory of Open Access Journals (DOAJ),

Journal Seek, Scientific Commons,

Food and Agricultural Organization (FAO), CABI and Scopus
Journal of Agricultural Extension

Vol. XX (X) XXXXXX, 20XX

ISSN(e): 24086851; ISSN(Print); 1119944X

http://journal.aesonnigeria.org

http://www.ajol.info/index.php/jae

Email: editorinchief@aesonnigeria.org

\section{Introduction}

In Nigeria, the rural areas are the food and fibre producing centres. They are also the seed bed of national population which serves to replenish the human resources of the urban centres (Olawoye, 2010). Rural women are involved at all stages of agricultural enterprises. They are responsible for about $80 \%$ of all food items produced (Rahaman, 2004), (FAO, 1992), 70\% of food production and $50 \%$ of the domestic food storage in the country (Mgbada, 2002). In addition, they form an active and reserve labour force but they rarely own the means of productions, suggesting that the position of women in agricultural development cannot be over emphasized (Rahman, 2004; World Bank, 2003).

The growth enhancement support scheme (GESS) was designed as a component of the agricultural transformation agenda (ATA) of the federal government. ATA was the government response to the oil crisis that has riddled the agricultural sector in the past and sought to put agricultural growth at the centre of the government's development objective given its critical role for food security and economic diversification (Umeh and Nwachukwu, 2015).

At inception, the broad objective of growth enhancement scheme (GESS) was to achieve food security for the nation at the macro level, and increase household income for the farmers at the micro level. The scheme was designed to encourage stakeholders in the fertilizer value chain to work together to improve productivity, household food security and raise the income of the farmer by providing direct subsidy through the supply of discounted fertilizers and seeds.

For many years, agro-inputs supply and distribution in Nigeria has been limited by ambiguity in government policy regarding production, liberalization, regulation and subsidy administration. It has been fraught with so many inefficiencies, fraud and discrepancies with clamming that the inputs do not get to them at the required times and recommended rates or at all. Government at the federal and state levels were spending a lot of money on farm inputs which were not reaching the intended 
Creative commons User License: CC BY-NC-ND

Abstracted by: EBSCOhost, Electronic Journals Service (EJS),

Google Scholar, Directory of Open Access Journals (DOAJ),

Journal Seek, Scientific Commons,

Food and Agricultural Organization (FAO), CABI and Scopus
Journal of Agricultural Extension

Vol. XX (X) XXXXXX, 20XX

ISSN(e): 24086851; ISSN(Print); 1119944X

http://journal.aesonnigeria.org

http://www.ajol.info/index.php/jae

Email: editorinchief@aesonnigeria.org

beneficiaries (small holder farmers) and thus, had no significant impact on the national food output.

To address this, the federal government decided from the 2012 farming season to opt out of direct procurement and distribution of inputs and instead instituted the growth enhancement support scheme (GESS) aimed at delivering subsidized farm inputs to farmers through an electronic wallet. Under the scheme, an accredited farmer will receive agro inputs allocation through an $\mathrm{e}$ - wallet that hosts unique voucher numbers sent to his or her phone, and go to an accredited agro dealer to redeem his inputs. It is expected that this should lead to improvements in agro inputs distribution and marketing by private sector, as well as consequent improvement in crop and agricultural productivity, and profitability for both the input supplied dealer and farmer (Umeh and Nwachukwu, 2015; Etuh, 2012). It is based on the above background information that this paper examines the participation of rural women in the growth enhancement support scheme (GESS) in Abia State Nigeria.

\section{Problem statement}

Even with the decline in the agricultural sector, agriculture continued to contribute about 40\% to Nigeria's Gross Domestic Product (GDP) in 2010-2011 (this is based on Nigeria Bureau of Statistics Economic Outlook 2012 Report). Agriculture is predominantly practiced in the rural areas of the country; hence, there is the need to ensure that farmers in the rural areas get access to farm input such as fertilizers, seeds and information to enhance their productivity. Women from the majority of the rural areas are involved at all stages of agricultural enterprises, responsible for about $70 \%$ of food production and $50 \%$ of the domestic food storage in the country (Mgbada, 2002). In addition, they form an active and reserve labour force but they rarely own the means of productions. GESS programme is all about distribution of agro input to the rural poor farmers. By assessing rural women participation in the growth enhancement support scheme in Abia State Nigeria, this research work would provide guidance to the GESS stakeholders to implement measures that will improve the regular supply of adequate quantity and quality of fertilizers to meet the demand of Nigerian farmers especially the women who make up the majority of the 
Creative commons User License: CC BY-NC-ND

Abstracted by: EBSCOhost, Electronic Journals Service (EJS),

Google Scholar, Directory of Open Access Journals (DOAJ),

Journal Seek, Scientific Commons,

Food and Agricultural Organization (FAO), CABI and Scopus
Journal of Agricultural Extension

Vol. XX (X) XXXXXX, 20XX

ISSN(e): 24086851; ISSN(Print); 1119944X

http://journal.aesonnigeria.org

http://www.ajol.info/index.php/jae

Email: editorinchief@aesonnigeria.org

agricultural work force. As such, the added knowledge on which factors have the greatest influence on GESS participation will help administrators make more informed decisions on how to promote active participation of all the beneficiaries in the programme to achieve its set objectives within the study area and beyond.

\section{Objectives of the study}

The broad objective of the study is to assess participation of the rural women in the growth enhancement support scheme in Abia State.

Specifically, the paper was designed to:

i. describe the socio economic characteristics of the respondents;

ii. analyse the level of rural women participation in the GESS programme;and

iii. identify major factors affecting active participation of women in the programme in the study area.

\section{Hypothesis}

$\mathrm{HO}$ : there is no relationship between the socio - economic characteristics of the respondents and their level of participation in GESS in the study area.

\section{Methodology}

Study area:

The study was conducted in Abia State of Nigeria. Abia state was created on the $27^{\text {th }}$ day of august 1991 from the old Imo state, with its capital at Umuahia. Abia state is made up of 17 LGAs. The climate is tropical with dry and raining seasons. It has an annual rain fall of about $668 \mathrm{~mm}$, a large portion of the people are engaged in agriculture and they produce mostly yam, maize, cocoyam, rice, cassava, plantain and cashew. The people are mostly farmers which constitute about $70 \%$ of the rural population. The predominant soil of the area is sandy loan while the natural vegetation is the tropical rain forest and is characterized by two distinct seasons, dry and wet season, (Iheke, 2006). Some of the people engage in non - farm economic 
Creative commons User License: CC BY-NC-ND

Abstracted by: EBSCOhost, Electronic Journals Service (EJS),

Google Scholar, Directory of Open Access Journals (DOAJ),

Journal Seek, Scientific Commons,

Food and Agricultural Organization (FAO), CABI and Scopus
Journal of Agricultural Extension

Vol. XX (X) XXXXXX, 20XX

ISSN(e): 24086851; ISSN(Print); 1119944X

http://journal.aesonnigeria.org

http://www.ajol.info/index.php/jae

Email: editorinchief@aesonnigeria.org

activities, like craft making, carpentry and brick laying. Livestock are also kept especially on a small hider basis (Nwaru, 2005).

Sampling Procedure:

The sample population includes all the women in the study area who are actively involved in farming. A multi-stage sampling procedure was used in the study. Abia state is divided into three (3) agricultural zones namely: Aba, Umuahia and Ohafia agricultural zones.

The first stage involves the purposive selection of Umuahia zone for proximity and effective coverage while in the second stage; one Local Government Area (LGA) was randomly selected out of the three LGAs in Umuahia Zone. The LGA comprises of two ADP blocks which is made up of five circles each. In the third stage, three circles where randomly selected from each of the blocks making it a total of 6 blocks.

Finally, 20 women who are actively involved in farming were randomly selected from each circle, making it a total of 120 rural women farmers. However, questionnaires from 116 respondents were used for data processing because four questionnaires were rejected for inadequacy in information provided. Data for the analysis were obtained using a structured questionnaire. Objectives i and ii were analyzed with descriptive statistics such as frequency counts, mean and percentages while Relationship between socio-economic characteristics of the respondent and their level of participation in GESS in the study area was measured with Probit model analysis.

Factors affecting participation of women in the scheme was measured using a 5 item statement rated on a 4-point Likert type scale of strongly agree (4), agree (3), disagree (2), and strongly disagree (1). A midpoint was obtained thus, $4+3+2+1=10 / 4=2.5$. Based on the mid score decision rule, any mean score less than or equal to 2.5 is graded as strong disagreement. Any mean score between 2.5 to 3.0 is graded as agree while mean scores greater than 3.0 implied strong agreement in the statement as a factors affecting participation of women in the scheme. 
Creative commons User License: CC BY-NC-ND

Abstracted by: EBSCOhost, Electronic Journals Service (EJS),

Google Scholar, Directory of Open Access Journals (DOAJ),

Journal Seek, Scientific Commons,

Food and Agricultural Organization (FAO), CABI and Scopus
Journal of Agricultural Extension

Vol. XX (X) XXXXXX, 20XX

ISSN(e): 24086851; ISSN(Print); 1119944X

http://journal.aesonnigeria.org

http://www.ajol.info/index.php/jae

Email: editorinchief@aesonnigeria.org

\section{Results and Discussion}

\section{Socio-economic Characteristics of the Respondents:}

Table 1 shows that more (43.96\%) of the rural women were above 40 years, while only about 8.68 percent is between the age brackets of $18-25$ years. The majority $(66.37 \%)$ was married while, $55.18 \%$ of the women had up to secondary education, and $28.44 \%$ had tertiary qualification. Meanwhile, about $14.65 \%$ out of the total respondents did not have any form of formal education. The table also shows that $63.79 \%$ of the respondents have about 5 - 8 persons living with them in the same household while their income level indicated that the majority (52.59\%) of the respondents earned between $\$ 16,000$ - $\$ 30,000$ on a monthly basis. The results from socio - economic characteristics of the respondents imply that the women were in their active years. This is in agreement with the findings of Afolabi (2008) that older women have positive significant contribution to the development of agriculture; compared to the younger women who are engaged in schooling or trading. The household size indicates that they have enough mouths to feed therefore need assistance from the government to sustain their income. The women farmers in the study area were relatively educated. Education is an important factor in utilization of innovation. Nwachukwu (2005) also noted that the level of education one has will affect the way one receives a message. In view of this, the educational status of the farmers in the study area will enhance their participation in the scheme. Meanwhile their income level from agricultural production is below average confirming the report of NBS, 2014 that the contribution of agriculture to GDP (Gross Domestic Product) is relatively low compared to the oil and gas sector (NBS, 2014). This crop of women actually needs all the assistance they can get from the government to take their agricultural production to a profitable level. 
Creative commons User License: CC BY-NC-ND

Abstracted by: EBSCOhost, Electronic Journals Service (EJS),

Google Scholar, Directory of Open Access Journals (DOAJ),

Journal Seek, Scientific Commons,

Food and Agricultural Organization (FAO), CABI and Scopus
Journal of Agricultural Extension

Vol. XX (X) XXXXXX, 20XX

ISSN(e): 24086851; ISSN(Print); 1119944X

http://journal.aesonnigeria.org

http://www.ajol.info/index.php/iae

Email: editorinchief@aesonnigeria.org

Table 1: Percentage distribution of selected socio-economic characteristics of the participating farmers

\begin{tabular}{ll}
\hline Variables & Percentages \\
\hline Age & \\
$18-25$ & 8.63 \\
$26-32$ & 18.97 \\
$33-39$ & 28.44 \\
40 and above & 43.96 \\
Marital status & \\
Single & 6.03 \\
& 66.37 \\
Married & \\
Widow & 24.14 \\
Divorced & 3.44 \\
Educational Level & \\
No formal Education & 14.65 \\
Primary Education & 12.94 \\
Secondary Education & 42.24 \\
Tertiary Education & 28.44 \\
Others & 1.73 \\
Household size & \\
1-4 persons & 17.24 \\
5-8 persons & 63.79 \\
9-12 persons & 18.97 \\
Income (A) & \\
5,000-15,000 & 19.82 \\
15,000-30,000 & 52.59 \\
30,000-45,000 & 25.5 \\
Above 45,000 & 2.08 \\
Occupation & \\
Farming & 69.82 \\
Trading & 25.00 \\
Civil servant & 33.62 \\
Others & 3.44 \\
\hline Source: Computed from field survey data, 2015 \\
\end{tabular}

\section{Level of Rural Women Participation in the GESS Programme}

Only $43.96 \%$ of the respondents confirmed that they have heard of the Growth Enhancement Support Scheme (table 2). This indicates that the scheme had below average awareness level in the study area. However, $35.34 \%$ of the rural women registered and participated in the GESS programme. Therefore, the programme recorded low percentage of registration and participation of the women in the study area. 
Creative commons User License: CC BY-NC-ND

Abstracted by: EBSCOhost, Electronic Journals Service (EJS), Google Scholar, Directory of Open Access Journals (DOAJ), Journal Seek, Scientific Commons,

Food and Agricultural Organization (FAO), CABI and Scopus

\author{
Journal of Agricultural Extension \\ Vol. XX (X) XXXXXX, 20XX \\ ISSN(e): 24086851; ISSN(Print); 1119944X \\ http://journal.aesonnigeria.org \\ http://www.ajol.info/index.php/iae \\ Email: editorinchief@aesonnigeria.org
}

Again $42.24 \%$ of the respondents received text messages while $57.76 \%$ reported that they did not receive text message(s) from the scheme. $49.69 \%$ of the respondents actually received fertilizer from the scheme, while $43.10 \%$ indicated that they did not receive any input. However, $11.20 \%$ of the rural women are indifferent of the whole process.

This result revealed that awareness level and registration of the women in the programme was below average, therefore their level of participation was also below average. Effectiveness of the scheme can be improved upon by raising the campaign and awareness level in order to get more women registered to participate in the programme. Adequate fertilizers and other required agro-input should be supplied to the registered farmers. This will improve their productivity and help eradicate hunger and poverty; as recommended by Nwachukwu, (2007).

Table 2: Distribution of respondents according to their level of participation in GESS

\begin{tabular}{ll}
\hline Variables & Percentage (\%) \\
\hline Have you heard about this programme GESS? & \\
Yes & 43.96 \\
No & 27.58 \\
Don't know & 28.43 \\
Did you register and participated in the programme & \\
Yes & \\
No & 35.34 \\
Don't know & 56.03 \\
Did you receive text message From GESS & 8.62 \\
Yes & \\
No & \\
Don't Know & 42.24 \\
did you receive fertilizer and other inputs from GESS & 50.86 \\
Yes & 6.90 \\
No & \\
Don't Know & \\
Sms/text delivery rate & 45.69 \\
Weekly & 43.10 \\
Monthly & 11.20 \\
Yearly & \\
Each farming season & 2.59 \\
Total & 4.31 \\
\hline Source: Computed from field survey data 2015 & 19.82 \\
\hline & 73.28 \\
& 100 \\
\hline & \\
\hline
\end{tabular}

Source: Computed from field survey data, 2015 
Creative commons User License: CC BY-NC-ND

Abstracted by: EBSCOhost, Electronic Journals Service (EJS),

Google Scholar, Directory of Open Access Journals (DOAJ),

Journal Seek, Scientific Commons,

Food and Agricultural Organization (FAO), CABI and Scopus
Journal of Agricultural Extension

Vol. XX (X) XXXXXX, 20XX

ISSN(e): 24086851; ISSN(Print); 1119944X

http://journal.aesonnigeria.org

http://www.ajol.info/index.php/jae

Email: editorinchief@aesonnigeria.org

\section{Factors affecting participation of the respondent in the scheme}

Entries in Table 3 shows that the respondents strongly agreed that low level of awareness about the programme (with mean score of 3.45) and inability to register for the scheme (3.77) were the major constraints effecting their participation in the GES program. Meanwhile, absence of extension agent (3.22) was another constraint which also points to low level of awareness about the programme.

There is need to raise the awareness of the GES scheme to enlighten the farmers more on the benefits of the programme and encourage their participation. Arokoyo (2003) reports that the village level extension agents are the most effective source of information for farmers. Effort should be made by the government to post more extension agents to the rural areas to raise awareness of such programs at the village level, then educate and encourage active participation of women in the programme. The process of registration should be reviewed to eliminate bureaucratic bottlenecks that hinder prompt and easy registration of farmers in the GESS programme.

Table 3: Percentage distribution of the respondent according to the factors affecting active participation of rural women in GESS in the study area

\begin{tabular}{|c|c|}
\hline Variables & Mean \\
\hline $\begin{array}{l}\text { Low level of awareness about the } \\
\text { scheme }\end{array}$ & 3.45 \\
\hline Inability to register for the scheme & 3.77 \\
\hline Lack of extension agent & 3.22 \\
\hline $\begin{array}{l}\text { Hijack of the scheme by the } \\
\text { rich/wealthy }\end{array}$ & 2.93 \\
\hline $\begin{array}{l}\text { Farmers do not believe in the } \\
\text { scheme }\end{array}$ & 2.77 \\
\hline
\end{tabular}


Creative commons User License: CC BY-NC-ND

Abstracted by: EBSCOhost, Electronic Journals Service (EJS),

Google Scholar, Directory of Open Access Journals (DOAJ),

Journal Seek, Scientific Commons,

Food and Agricultural Organization (FAO), CABI and Scopus
Journal of Agricultural Extension

Vol. XX (X) XXXXXX, 20XX

ISSN(e): 24086851; ISSN(Print); 1119944X

http://journal.aesonnigeria.org

http://www.ajol.info/index.php/jae

Email: editorinchief@aesonnigeria.org

\section{Relationship Between the Socio-Economic Characteristics of the Women and their Level of participation in the GESS Programme.}

The analysis showed that the coefficient for age $\left(-1.105^{*}\right)$ was negative and significant at $10 \%$ level of probability. The implication is that as age of these women increases, their level of participation in the GESS decreases in Abia State. Bonaban, Nwaru, (2005) also agree that age of the farmer can have a profound effect on participation in agricultural programs and technology adoption.

Coefficient for monthly income $\left(-1.915^{\star}\right)$ was also negative and significant. The implication is that as the monthly income of the women increases, their level of participation in GESS decreases in Abia State. This will re-direct the scheme at development level to target resource poor women for active participation in the programme. The coefficient of awareness (0.205) was positive and significant at $10 \%$ level of probability in Abia state. This implies that the rural women probability of participating in the GESS programme increases as the awareness level of the programme increases in Abia state. Concerted efforts should therefore be made to increase the awareness and acceptability of the GESS programme in the state through the use of information and communication technology devices (ICTs) and other mass media means. Ake, (2010) asserts that information and communication technologies (ICTS) are being used in information dissemination in all agricultural sub-sectors to arouse awareness, encourage participation and increase production. 
Creative commons User License: CC BY-NC-ND

Abstracted by: EBSCOhost, Electronic Journals Service (EJS),

Google Scholar, Directory of Open Access Journals (DOAJ),

Journal Seek, Scientific Commons,

Food and Agricultural Organization (FAO), CABI and Scopus
Journal of Agricultural Extension

Vol. XX (X) XXXXXX, 20XX

ISSN(e): 24086851; ISSN(Print); 1119944X

http://journal.aesonnigeria.org

http://www.ajol.info/index.php/iae

Email: editorinchief@aesonnigeria.org

Table 4: Relationship between the socio-economic characteristics of the respondent and their level of participation in GESS in Abia state

\begin{tabular}{llll}
\hline Variables & Coefficient & Std error & t-Values \\
\hline Constant & .309 & .298 & $1.034^{\star}$ \\
Age $\left(\mathbf{X}_{1}\right)$ & .004 & .003 & $-1.105^{\star}$ \\
Awareness $\left(\mathbf{X}_{2}\right)$ & .205 & .106 & $1.926^{\star}$ \\
Marital status $\left(\mathbf{X}_{3}\right)$ & .090 & .110 & .815 \\
Level of education $\left(\mathbf{X}_{4}\right)$ & .003 & 0.13 & .200 \\
Family size $\left(\mathbf{X}_{5}\right)$ & 006 & .000 & .673 \\
Monthly income $\left(\mathbf{X}_{6}\right)$ & .041 & .021 & $-1.915^{\star}$ \\
Membership to social & .061 & .109 & .559 \\
organization $\left(\mathbf{X}_{\mathbf{7}}\right)$ & & .109 & .961 \\
Extension contact $\left(\mathbf{X}_{8}\right)$ & .105 & &
\end{tabular}

${ }^{\star} \mathrm{P}<0.05$

\section{Conclusion and Recommendations}

The programme recorded low percentage of registration and participation of the women in the study area. Poor awareness, bureaucratic bottlenecks in the registration process, delay in receiving text messages and agro-inputs limited active participation of the rural women in the programme and inversely the general performance of GESS in the study area. The study further revealed that bureaucratic bottlenecks in the process of registration as well as absence of extension agents among other factors had constrained the effective participation of farmers in the project. There should be thorough reappraisal of the implementation strategies to encourage active participation of farmers in the GESS programme in Abia state. It is recommended that the process of farmer's registration should be reviewed and made easier for the farmers to enroll in the programme. Since awareness has positive influence on participation in the programme, there is need for extensive public sensitization and enlightenment campaigns about GESS using the ICTS and other mass media means especially at the grass root level. Again farmers should organize themselves into cooperative groups to reposition themselves for easy access of government's programs and assistance while 
Creative commons User License: CC BY-NC-ND

Abstracted by: EBSCOhost, Electronic Journals Service (EJS),

Google Scholar, Directory of Open Access Journals (DOAJ),

Journal Seek, Scientific Commons

Food and Agricultural Organization (FAO), CABI and Scopus
Journal of Agricultural Extension

Vol. XX (X) XXXXXX, 20XX

ISSN(e): 24086851; ISSN(Print); 1119944X

http://journal.aesonnigeria.org

http://www.ajol.info/index.php/jae

Email: editorinchief@aesonnigeria.org

government on their side should improve on the technicalities of Sms delivery and the quantity of input delivered through the scheme.

\section{References}

Afolabi, M. M., (2008). Women as pillars of national economy in Nigeria: A study of economic activities of rural women in six Local Government Areas of Ondo State. IAFFE Summer Conference, International Association for Feminist.

Ake J, C. (2010). Using information technology for agricultural extension in developing countries. Dial "A" for agriculture. Tupts University, Medford. October 2010. PP $3-10$.

Arokoyo, T. (2003). Response to the e-discussion, ICT application in Rural Extension and information Exchange. In book, F. INARZS - ICT transforming on ICT. $6^{\text {th }}$ consultative export meeting, Wageningen.

Etuh, T. (2012) "The Growth Enhancement Support Scheme (GESS)" Monitoring Report: Submitted to the Honourable Minister of Agriculture and Rural Development. By The Fertilizer Suppliers Association of Nigeria.

Food and Agriculture Organization of the United Nations (FAO) (1992) Nigeria: Rural Roads and Marketing Project-Identification report Rome. Sustainable development department, pp: 4.

Iheke, O. R. (2006) "Gender and Resource Use Efficiency in Rice Production Systems in Abia State of Nigeria", M. Sc. Thesis, Department of Agricultural Economics, Michael Okpara University of Agriculture, Umudike, Nigeria.

Mgbada J. U. (2002) "Production of Staple Crops by Rural Women in Enugu and Ebonyi States: -Lessons for Enhancing Poverty Alleviation Programmes". In: Olowu T A (Ed) Agricultural Extension and Poverty Alleviation in Nigeria, Proceeding of the Agricultural Extension Society of Nigeria, pp. 10-12.

National Bureau of Statistics (NBS). (2014). Nigerian Gross Domestic Products Reports.

Nwachukwu, I. and Ezeh (2007) Impact of Selected Rural Development Programme On poverty Alleviation in Ikwuano L.G.A of Abia State, Nigeria AJFAND Online 7(5): 1-17.

Nwachukwu, I. (2005). Agricultural Communication: Principles and Practice. Umuahia: lambhouse Publishers. 
Creative commons User License: CC BY-NC-ND

Abstracted by: EBSCOhost, Electronic Journals Service (EJS),

Google Scholar, Directory of Open Access Journals (DOAJ),

Journal Seek, Scientific Commons,

Food and Agricultural Organization (FAO), CABI and Scopus

\author{
Journal of Agricultural Extension \\ Vol. XX (X) XXXXXX, 20XX \\ ISSN(e): 24086851; ISSN(Print); 1119944X \\ http://journal.aesonnigeria.org \\ http://www.ajol.info/index.php/iae \\ Email: editorinchief@aesonnigeria.org
}

Nwaru, J. C. (2005). Determinants of farm and off-farm incomes and savings of food crop Farms in Imo State, Nigeria: Implications for poverty alleviation. The Nigerian Agricultural Journal, 36, 26 - 42.

Olawoye, J. E.; Okoye, O. and Eleri, A. (2010) Gender and Climate Change Toolkit for Policy Makers and Programme Developers Nigeria CAN / C4C / DFID / ICEED, Abuja. (ISBN 978-978-909-493-6)

Rahman S. A. (2004) "Gender Differential in Labour Contribution and Productivity in Farm Production Empirical Evidence from Kaduna State of Nigeria", Paper Presented at the National Conference on Family held at New Theatre Complex. Benue State University, Makurdi, Nigeria. 1st-5th March.

Umeh, O. J and Nwachukwu, I. (2015). Revamping Grassroots Agricultural Production through the Agricultural Extension Transformation Agenda. In contemporary issues in extension system and development. Nwachukwu, I. (Ed) (inpress). Pp $2-7$.

World Bank (2003). Nigeria: Women in Agriculture. In: Sharing Experiences Examples of Participating Approaches. The World Bank Group. The World Bank Participating Source book, Washington, D. C RetrievedJuly262011 from. http://www. worldbank. org/wbi/publications. Html 